\title{
RETICULOCYTE COUNT IN PATIENTS WITH RHEUMATOID ARTHRITIS, WITH OBSERVATIONS ON THE EFFECT OF GOLD THERAPY ON BONE MARROW FUNCTION
}

\author{
A. M. DENMAN*, H. HUBER $\dagger$, PHILIP H. N. WOOD + , AND J. T. SCOTT \\ From the Departments of Medicine and Haematology, Hammersmith Hospital, and the Postgraduate \\ Medical School of London
}

A variety of disturbances in the peripheral blood count may complicate gold therapy given to patients with rheumatoid arthritis. Relatively small doses of gold have caused leucopenia and thrombocytopenia, often associated with other manifestations of hypersensitivity (Price and Leichtentritt, 1943). Pancytopenia secondary to marrow aplasia has occurred less commonly, and usually only after large doses (Wintrobe, Stowell, and Roll, 1939; Marriott and Peters, 1950). Moreover, marrow depression may not be evident until many months after the course of gold has been completed (Sørensen, 1951). In recent years the incidence of these complications has been greatly reduced by limiting the amount of gold given in single injections and also in any one course (Empire Rheumatism Council, 1960).

Some drugs, such as thiouracil, produce abnormal blood counts infrequently, apparently because of individual idiosyncrasy (Bell and Mishtowt, 1951). Other drugs, such as nitrogen mustard, are predictably toxic to the bone marrow when given in adequate dosage (Wintrobe, Huguley, McLennan, and Lima, 1947). Both mechanisms have been incriminated in the marrow dysplasia caused by chloramphenicol, and reticulocytopenia and impaired utilization of radioactive iron have been demonstrated before changes occurred in the peripheral blood count (Krakoff, Karnofsky, and

\footnotetext{
Present addresses: * Department of Medicine, Southwestern Medical School, University of Texas, Dallas, Texas, School,

+ Department of Medicine, Medizinische Universitätsklinik, Innsbruck. Austria.

\pm Departments of Medicine, Veterans Administration Hospital and State University of New York at Buffalo Medical School, Buffalo, New York, U.S.A.
}

Burchenal, 1955; Rubin, Weisberger, Botti, and Storaasli, 1958). It was decided to investigate the possibility that similar changes might be detected after treatment with limited doses of gold in a small group of patients with rheumatoid arthritis.

\section{Material and Methods}

\section{General Procedure}

Gold Therapy.-Assessments of bone marrow function were made before and after treatment with gold in seven patients with definite or classical rheumatoid arthritis (Ropes, Bennett, Cobb, Jacox, and Jessar, 1959).

Table I (opposite) enumerates the salient features of these patients, including concurrent corticosteroid therapy, the duration of hospital treatment as an inpatient, the total amount of gold given, and the side-effects that were observed. All seven patients continued to take $4 \mathrm{~g}$. daily of some form of salicylate, but haematinic drugs were withheld during the period of study. Sodium aurothiomalate* $50 \mathrm{mg}$. intramuscularly, was injected weekly, and full blood counts were made on each occasion. The response to treatment was assessed by joint tenderness, graded $0=$ none, $1=$ slight, $2=$ moderate, and $3=$ severe, and by erythrocyte sedimentation rate (E.S.R.) in one hour by the Westergren method.

Reticulocyte Studies.-Reticulocyte counts were determined in these seven patients, daily on the in-patients and weekly on the out-patients, throughout the period of gold therapy.

In addition, reticulocyte counts were made:

(a) daily for a three-week period in:

(i) fifteen in-patients with various inflammatory diseases, including pulmonary tuberculosis, pneumonia, and subacute bacterial endocarditis; 
TABLE I

CLINICAL PARTICULARS OF PATIENTS STUDIED DURING GOLD THERAPY

\begin{tabular}{|c|c|c|c|c|c|c|}
\hline \multirow[b]{2}{*}{ Case No. } & \multirow[b]{2}{*}{ Age (yrs) } & \multirow[b]{2}{*}{ Sex } & \multirow{2}{*}{ Concurrent Steroid Therapy } & \multicolumn{3}{|c|}{ Gold Therapy } \\
\hline & & & & $\begin{array}{c}\text { Followed in Hospital } \\
\text { (wks) }\end{array}$ & Total Dose (mg.) & Side-Effects \\
\hline 1 & 45 & $\mathbf{M}$ & Prednisolone $10 \mathrm{mg.*}^{*}$ & 12 & 1,000 & $\mathrm{Nil}$ \\
\hline 2 & 53 & $\mathbf{M}$ & Nil & (OP) & 1,000 & Nil \\
\hline 3 & 38 & $\mathbf{F}$ & Nil & 14 & 1,000 & Nil \\
\hline 4 & 48 & $\mathbf{F}$ & Nil & 12 & 1,000 & Nil \\
\hline 5 & 65 & $\mathbf{F}$ & Prednisolone $10 \mathrm{mg.}^{*}$ & 14 & 1,000 & Eosinophilia \\
\hline 6 & 47 & $\mathbf{F}$ & Nil & 14 & 800 & $\begin{array}{l}\text { Eosinophilia, rash, } \\
\text { proteinuria, diarrhoea }\end{array}$ \\
\hline 7 & 53 & $\mathbf{F}$ & Nil & (OP) & 1,000 & Nil \\
\hline
\end{tabular}

* Both these patients had been taking corticosteroids for the preceding 6 months.

(ii) six in-patients with rheumatoid arthritis in remission and who had never received gold;

(iii) six normal subjects.

(b) isolated counts in three groups, each of forty patients with:

(i) definite or classical rheumatoid arthritis, whose disease was clinically active and in whom the E.S.R. exceeded $30 \mathrm{~mm}$. in the first hour;

(ii) clinically inactive rheumatoid arthritis, in whom the E.S.R. was less than $30 \mathrm{~mm}$., and most of whom had never received gold;

(iii) degenerative joint disease or musculoskeletal pains of uncertain cause, in all of whom the E.S.R. was less than $20 \mathrm{~mm}$.

\section{Haematological Techniques}

Blood Counts. - A full blood count included the estimation of haemoglobin, haematocrit, and total and differential white cell counts (Dacie and Lewis, 1963b), and also examination of a stained blood smear for platelets.

All reticulocyte counts were made by the same observer by a modification of the method of Trachtenberg (1931). Blood was withdrawn by venepuncture at the same time of day, with $0.1 \mathrm{ml} .3 .8$ per cent. sodium citrate as an anticoagulant, and was mixed immediately with an equal volume of brilliant cresyl blue. Smears were made within 20 to 30 minutes, dried in air, and the number of reticulocytes per 10,000 red blood cells was counted with an oil-immersion lens.

The absolute reticulocyte count, the product of the red cell count and the percentage of reticulocytes, is theoretically more informative than the percentage reticulocyte count because it reflects changes in the total number of circulating reticulocytes. The errors in counting erythrocytes are well known (Dacie and Lewis, 1963a), and these modify the value of, and falsely accentuate fluctuations in, the absolute reticulocyte count. In preliminary studies, day to day variations were observed in the red cell count that were not reflected by equivalent fluctuations in the haematocrit, presumably due to errors in determining the former. Throughout the subsequent studies no variation in erythrocyte morphology was observed, and so changes in the haematocrit were considered to parallel those in the red cell count. The more accurate haematocrit values were used as the reference standard for changes in red cell mass, and the reticulocyte index was devised. This was derived from the product of the haematocrit and the reticulocyte count, both expressed as percentages, and was used as an estimate of the absolute number of reticulocytes per unit volume of blood.

In the seven patients given gold, bone marrow was aspirated from the sternum of five and from the iliac crest of the other two before the course of gold. Sternal marrow aspirations were repeated in all seven patients at the end of the course. Smears of the aspirate were examined for the cellularity of the fragments, and differential counts were made on 1,000 nucleated cells. The smears were examined also for their iron content, both extracellularly and as granules within the erythroblasts (Dacie and Lewis, 1963c).

Iron Metabolism.-Serum iron and total iron-binding capacity were determined by the methods of King and Wootton (1956) in all seven patients before and after treatment with gold.

Erythropoiesis was assessed with radioactive iron in six patients before and immediately after the course of gold. The methods used were based on those of Finch, Gibson, Peacock, and Fluharty (1949) and of Huff, Tobias, and Lawrence (1952), as described by Dacie and Lewis (1963d). The rate of disappearance of the iron from the plasma (plasma half-clearance time) was estimated by counting the radioactivity of plasma samples 
obtained at timed intervals after injection over a period of 1 to 2 hours. The amount of $\mathrm{Fe}^{59}$ subsequently appearing in the circulating erythrocytes was estimated by counting whole blood samples obtained daily during the first 10 days, and the maximum value was regarded as the radio-iron utilization. In addition, surface counting was carried out. Particular attention was paid to the counts observed over the upper portion of the sacrum, as a measure of bone marrow activity. The sacral count 5 minutes after injection was taken as 100 per cent., and subsequent counts were expressed as a percentage of this value, from which was selected the maximum sacral uptake.

\section{Gold Therapy}

\section{Results}

Treatment with gold was associated with clinical improvement in all seven patients. Joint tenderness decreased by one or two grades, and the mean E.S.R. fell from 60 to $20 \mathrm{~mm}$. (Table II).

In accordance with the findings in most therapeutic trials of gold, there was a slight increase in the mean haematocrit. There was no obvious decrease in the number of platelets seen in stained blood films, and the total white cell count was unaltered, at no time falling below 5,000 cells per cu. $\mathrm{mm}$. (Table II).

Eosinophilia was noted after $650 \mathrm{mg}$. gold in two patients, the absolute count reaching 1,200 and 1,120 eosinophils per cu. mm. The eosinophilia subsided without interrupting the series of injections, but in one patient (Case 6) clinical toxicity, manifested by a rash, proteinuria, and persistent diarrhoea, ensued after a further $150 \mathrm{mg}$. had been given, and so gold therapy was discontinued. The other patient (Case 5), who completed the course of gold without further incident, was taking prednisolone throughout.
The two patients with peripheral eosinophilia showed a slight increase in mature eosinophils in smears of the bone marrow aspirated at the end of therapy. Apart from this, the cellularity and differential cell counts of the marrow smears, both before and after therapy, were within normal limits, and there was no evidence of the development of hypoplasia. Six patients showed moderate to severe depletion of marrow iron stores before treatment, and in five of them the appearance was unaltered after treatment. The sixth patient (Case 5) showed an increase in the amount of extracellular iron and in the number of erythroblasts containing iron granules after the course of gold. There was no correlation between the reticulocyte count and the severity of the iron deficiency as judged by the marrow iron content.

The low serum iron values and the percentage saturation of the serum iron-binding capacity were not significantly altered by treatment with gold (Table II). The rapid clearance of radioiron from the plasma, characteristic of rheumatoid arthritis (Freireich, Ross, Bayles, Emerson, and Finch, 1957), was not affected by gold therapy. In the patient who developed gold toxicity (Case 6) there was some reduction in sacral uptake and in subsequent utilization of radioiron, but in the other patients these ferrokinetic parameters remained within normal limits and confirmed the morphological evidence that bone marrow function had not been depressed.

\section{Reticulocyte Studies}

In the patients treated with gold the mean reticulocyte count fell from $1 \cdot 2$ to 0.3 per cent. after

TABLE II

EFFECT OF GOLD THERAPY ON THE PERIPHERAL BLOOD COUNT AND ON IRON METABOLISM

\begin{tabular}{|c|c|c|c|c|c|c|c|c|c|c|c|c|c|c|c|c|c|c|}
\hline \multirow{3}{*}{$\begin{array}{l}\text { Case } \\
\text { No. }\end{array}$} & \multicolumn{4}{|c|}{ Therapeutic Assessment } & \multicolumn{4}{|c|}{ Peripheral Blood Count } & \multirow{2}{*}{\multicolumn{2}{|c|}{$\begin{array}{c}\text { Serum Iron } \\
(\mu \mathrm{g} . / 100 \mathrm{ml} .)\end{array}$}} & \multirow{2}{*}{\multicolumn{2}{|c|}{$\begin{array}{c}\text { Total } \\
\text { Iron-Binding } \\
\text { Capacity }\end{array}$}} & \multicolumn{6}{|c|}{ Fe59 Studies } \\
\hline & \multicolumn{2}{|c|}{$\begin{array}{c}\text { Joint } \\
\text { Tenderness } \\
\text { (grade) }\end{array}$} & \multicolumn{2}{|c|}{$\underset{(\mathrm{mm} . / \mathrm{hr})}{\text { E.S.R. }}$} & \multicolumn{2}{|c|}{$\begin{array}{l}\text { Hematocrit } \\
\text { (Per cent.) }\end{array}$} & \multicolumn{2}{|c|}{$\begin{array}{l}\text { White Blood } \\
\text { Cell Count* } \\
\text { (per cu. mm. } \\
\times 1000)\end{array}$} & & & & & \multicolumn{2}{|c|}{$\begin{array}{c}\text { Plasma Half } \\
\text { Clearance } \\
\text { Time (min.) }\end{array}$} & \multicolumn{2}{|c|}{$\begin{array}{c}\text { Max. Sacral } \\
\text { Uptake } \\
\text { (Per cent.) }\end{array}$} & \multicolumn{2}{|c|}{$\begin{array}{l}\text { Utilization } \\
\text { (Per cent.) }\end{array}$} \\
\hline & B & $\mathbf{A}$ & B & $\mathbf{A}$ & B & $\mathbf{A}$ & B & $\mathbf{A}$ & B & $\mathbf{A}$ & B & $\mathbf{A}$ & $\mathbf{B}$ & $\mathbf{A}$ & B & $\mathbf{A}$ & B & $\mathbf{A}$ \\
\hline 1 & 3 & 1 & 10 & 6 & $41 \cdot 5$ & $41 \cdot 0$ & $9 \cdot 0$ & $10 \cdot 0$ & 38 & 82 & 312 & 231 & 27 & 27 & 165 & 158 & 90 & 90 \\
\hline 2 & 1 & 0 & 37 & 14 & $42 \cdot 0$ & $43 \cdot 0$ & $6 \cdot 0$ & $6 \cdot 1$ & 52 & 51 & 312 & 321 & 30 & 25 & 188 & 190 & 90 & 90 \\
\hline 3 & 2 & 1 & 62 & 15 & $42 \cdot 5$ & $43 \cdot 0$ & $7 \cdot 0$ & $6 \cdot 0$ & 27 & 27 & 318 & 318 & 16 & 35 & 160 & 162 & 90 & 90 \\
\hline 4 & 2 & 1 & 94 & 24 & $32 \cdot 0$ & $38 \cdot 5$ & $6 \cdot 0$ & $7 \cdot 0$ & 27 & 60 & 258 & 267 & 37 & 29 & 178 & 165 & 86 & 90 \\
\hline 5 & 2 & 0 & 68 & 17 & $31 \cdot 0$ & $45 \cdot 0$ & $7 \cdot 0$ & $6.0 \mathrm{E}$ & 20 & 15 & 255 & 220 & $18 \cdot 5$ & 30 & 166 & 165 & 90 & 91 \\
\hline $6+$ & 3 & 1 & 100 & 37 & $34 \cdot 5$ & $37 \cdot 0$ & $7 \cdot 1$ & $9 \cdot 0 \mathrm{E}$ & 12 & 20 & 186 & 312 & 18 & 31 & 188 & 155 & 96 & 78 \\
\hline 7 & 2 & 0 & 52 & 27 & $46 \cdot 0$ & $44 \cdot 0$ & $9 \cdot 0$ & $10 \cdot 1$ & 77 & 20 & 300 & 300 & \multicolumn{6}{|c|}{ (ferrokinetic studies not repeated) } \\
\hline
\end{tabular}


treatment. The mean reticulocyte index decreased from 46 to 13, and it was concluded that the absolute reticulocyte count was reduced in a like manner. Daily reticulocyte counts on the patients in hospital revealed a mean day to day fluctuation of approximately 1.0 per cent. during the first week of treatment (Table III). As the activity of the disease subsided (Table II), the decrease in the reticulocyte count was accompanied by a reduction in the day to day fluctuation to $0 \cdot 2$ per cent. during the week before discharge from hospital. Fig. 1 illustrates the decline in the variation and level of the reticulocyte count in one patient.

In the additional patients studied, the mean reticulocyte count was significantly higher in the forty patients with active rheumatoid arthritis than in the patients with inactive rheumatoid arthritis or with non-inflammatory joint complaints (Table IV, overleaf; $\mathbf{P}<0 \cdot 001$ ). The daily reticulocyte counts showed that day-to-day fluctuation did not amount to more than 0.3 per cent. in normal subjects. The variation in patients with inflammatory diseases other than rheumatoid arthritis did not exceed the normal value, even when the E.S.R. was markedly elevated.

Fig. 2, overleaf, illustrates these findings, and demonstrates that the reticulocyte count is normal in patients with rheumatoid arthritis in remission who had never received treatment with gold.
Fig. 1.-Reticulocyte counts and disease activity during gold therapy in Case 5. Reticulocyte counts on alternate days are shown during the period in hospital; weekly counts are shown thereafter. This patient was taking prednisolone throughout.

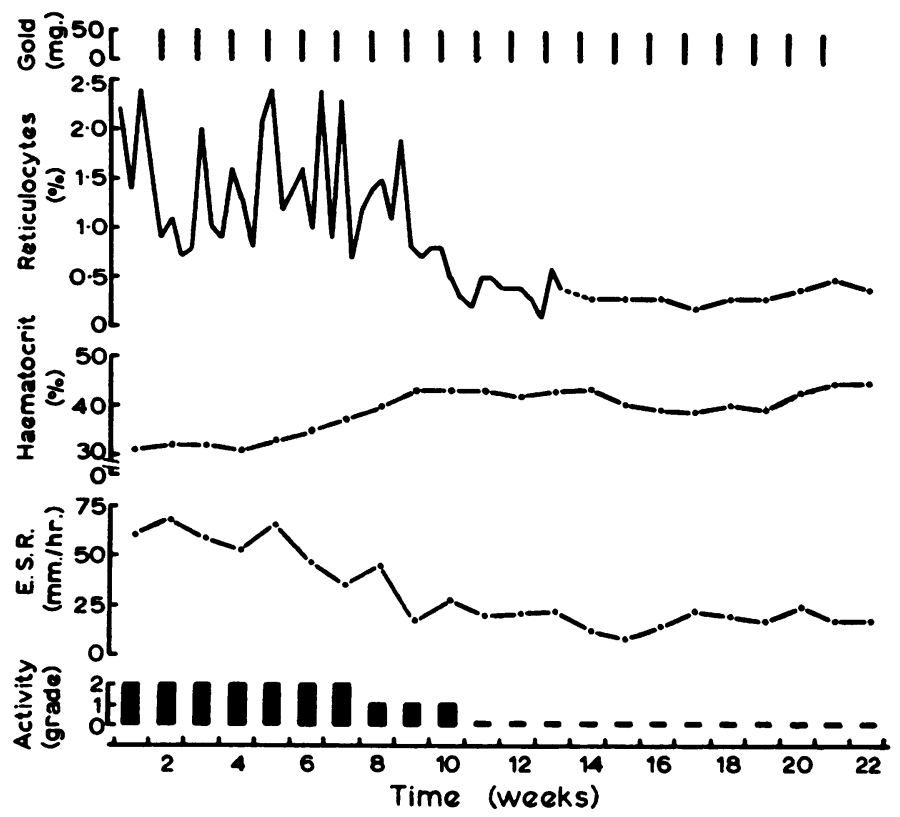

TABLE III

EFFECT OF GOLD THERAPY ON THE RETICULOCYTE COUNT

\begin{tabular}{|c|c|c|c|c|c|c|c|c|c|c|}
\hline \multirow{3}{*}{ Case No. } & \multicolumn{2}{|c|}{$\begin{array}{l}\text { Reticulocyte Count } \\
\text { (Per cent.) }\end{array}$} & \multicolumn{2}{|c|}{ Reticulocyte Index } & \multicolumn{6}{|c|}{$\begin{array}{l}\text { Variation in Daily Reticulocyte Count during Hospital Treatment } \\
\text { (Per cent.) }\end{array}$} \\
\hline & \multirow{2}{*}{ B } & \multirow{2}{*}{$\mathbf{A}$} & \multirow{2}{*}{ B } & \multirow{2}{*}{$\mathbf{A}$} & \multicolumn{3}{|c|}{ First Week } & \multicolumn{3}{|c|}{ Week Before Discharge } \\
\hline & & & & & Max. & Min. & Difference & Max. & Min. & Difference \\
\hline 1 & $1 \cdot 3$ & $0 \cdot 4$ & 34 & 16 & $1 \cdot 3$ & $0 \cdot 5$ & $0 \cdot 8$ & $0 \cdot 7$ & 0.5 & $0 \cdot 2$ \\
\hline 2 & $0 \cdot 8$ & $0 \cdot 3$ & 52 & 13 & & & (out-patient) & & & \\
\hline 3 & 0.9 & $0 \cdot 3$ & 39 & 13 & $1 \cdot 0$ & 0.6 & 0.4 & 0.6 & $0 \cdot 4$ & $0 \cdot 2$ \\
\hline 4 & $2 \cdot 0$ & $0 \cdot 2$ & 61 & 9 & $2 \cdot 2$ & $0 \cdot 8$ & $1 \cdot 4$ & 0.6 & $0 \cdot 8$ & $0 \cdot 2$ \\
\hline 5 & $1 \cdot 9$ & $0 \cdot 5$ & 58 & 13 & $2 \cdot 3$ & 0.7 & $1 \cdot 6$ & $0 \cdot 4$ & $0 \cdot 3$ & $0 \cdot 1$ \\
\hline 6 & $0 \cdot 8$ & $0 \cdot 2$ & 30 & 12 & $1 \cdot 1$ & 0.6 & $0 \cdot 5$ & $0 \cdot 8$ & $0 \cdot 7$ & $0 \cdot 1$ \\
\hline 7 & 0.9 & 0.4 & 45 & 15 & & & (out-patient) & & & \\
\hline
\end{tabular}

B Before course of gold

A After course of gold 
TABLE IV

RETICULOCYTE COUNT IN ACTIVE RHEUMATOID ARTHRITIS, INACTIVE RHEUMATOID ARTHRITIS, AND NON-INFLAMMATORY RHEUMATIC CONDITIONS

\begin{tabular}{|c|c|c|c|c|c|}
\hline Diagnosis & & No. of Patients & Mean Age (yrs) & $\begin{array}{l}\text { Mean Haematocrit } \\
\text { (Per cent.) }\end{array}$ & $\begin{array}{l}\text { Mean reticulocyte Count } \\
\text { (Per cent.) }\end{array}$ \\
\hline Active Rheumatoid Arthritis & $\cdots$ & 40 & $48 \cdot 0$ & $38 \cdot 3$ & $0.9 \pm 0.30$ \\
\hline Inactive Rheumatoid Arthritis & $\cdots$ & 40 & $49 \cdot 0$ & $34 \cdot 8$ & $0 \cdot 5 \pm 0 \cdot 15$ \\
\hline Other Rheumatic Conditions & . & 40 & $43 \cdot 9$ & $45 \cdot 0$ & $0.4 \pm 0 \cdot 10$ \\
\hline
\end{tabular}

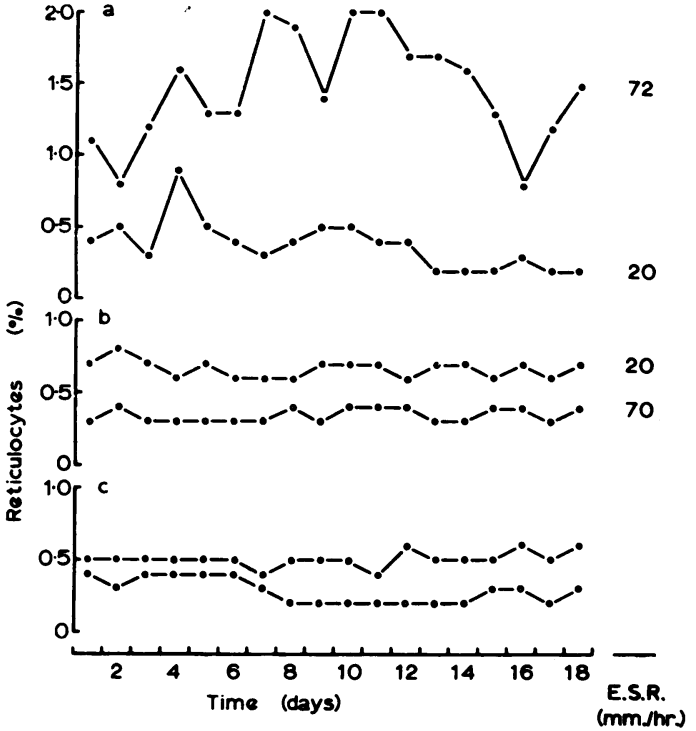

Fig. 2.-Daily reticulocyte counts:

(a) In a 64-year-old female patient with active rheumatoid arthritis (closed circles), and in a 47-year-old female patient with inactive rheumatoid arthritis (open circles); neither of these patients had received gold.

(b) In two male patients aged 24 and 65 , with active pulmonary tuberculosis.

(c) In two normal subjects, a 27-year-old male and a 29-year-old female.

\section{Discussion}

The range of error and the physiological variations in the reticulocyte count have been studied extensively by Marcussen (1938) and by Seip (1953). In the present study the accuracy of the count was verified by making films in triplicate from different blood specimens. Unidentified smears were examined, and no significant difference was found between the counts on films made from the same sample of blood. The day-to-day variation in normal subjects did not usually exceed $0 \cdot 3$ per cent. Serial counts in patients with various inflammatory diseases confirmed the observations of Hemmeler (1946) that the reticulocyte count in such conditions is normal or subnormal. Similarly, patients with non-inflammatory joint complaints were found to have normal reticulocyte counts.
Nilsson (1948) noted reticulocytosis in patients with rheumatoid arthritis, although he did not report sequential changes. In the present study a slight but definite rise in the reticulocyte count was observed in patients with active rheumatoid arthritis. Day-to-day fluctuations of the order of $1 \cdot 0$ per cent. were also found. In patients with inactive rheumatoid arthritis and in the seven patients with active rheumatoid who responded to gold therapy, both the total reticulocyte count and the daily variation were reduced to normal levels.

Many factors that may have contributed to an irregular reticulocytosis in rheumatoid arthritis were specifically excluded. Prior screening of the majority of the patients by a radioactive chromate technique had shown that there was no significant blood loss on each patient's oral drug régime (Scott, Porter, Lewis, and Dixon, 1961; Wood, Harvey-Smith, and Dixon, 1962). It is unlikely that the anaemia of rheumatoid arthritis was directly associated with the reticulocytosis. In two patients the reticulocyte count returned to normal before any change was observed in the haematocrit. Moreover, no correlation was observed between the haematocrit and the reticulocyte count in the group of forty patients with active rheumatoid arthritis. No convincing evidence of increased red cell destruction has been found in rheumatoid arthritis (Biechl, Stapleton, Woodbury, and Read, 1962), and a normal red cell survival was found in the three patients in the present series in whom this was studied.

Neither the injections of gold nor the venepunctures were related to the peaks and troughs of the fluctuating reticulocyte counts (vide Fig. 1). In a limited number of double-blind studies in which daily injections, most of which consisted of distilled water although a few were gold, were given, no relationship was found between the injections and the reticulocyte response. These findings, although linking the reticulocytosis with the activity of the rheumatoid disease, do not clarify the mechanism of the phenomenon. Possibly there is a disturbance in the release and subsequent maturation of red cells 
newly formed in the bone marrow (Jacobsen and Plum, 1943).

The fall in the reticulocyte count cannot be attributed to the direct action of gold on the bone marrow, as there was no other evidence of marrow depression and the reticulocyte count itself was still within the normal range. One patient (Case 6) developed eosinophilia followed by impaired radioiron uptake and utilization. It is possible that a bone marrow section at this time might have given evidence of hypoplasia. It is of interest that the other patient who developed eosinophilia, not infrequently the prelude to marrow hypoplasia, was on steroid therapy and showed no other signs of gold toxicity.

The evidence suggests that the toxic effects of gold on the bone marrow are based on individual idiosyncrasy. The possibility remains that bone marrow depression might occur more consistently with larger doses. The importance of the eosinophilia and other toxic effects as a prelude to marrow depression is emphasized by Case 6 . In this instance the marrow depression was mild and transient because gold therapy was stopped.

\section{Summary}

(1) Haemopoiesis in seven patients with rheumatoid arthritis was studied during a course of gold therapy. Serial blood counts, examination of bone marrow aspirates, and radio-iron studies, did not yield any evidence of consistent marrow depression. One patient manifested other evidence of gold toxicity, and there was some reduction in sacral uptake and subsequent utilization of radio-iron after gold, but no disturbance of the peripheral blood count was observed in the ensuing months.

(2) An irregular rise in the reticulocyte count was observed in patients with active rheumatoid arthritis. This rise disappeared when the disease was ameliorated by gold therapy, and was not observed in patients with inactive rheumatoid arthritis. It is concluded that an irregular reticulocytosis is an unexplained feature of rheumatoid disease activity.

The authors are grateful to Dr. S. Mitchell Lewis for much help and advice.

\section{REFERENCES}

Bell, G. O., and Mishtowt, G. I. (1951). Amer. J. Med., $10,68$.

Biechl, A., Stapleton, J. E., Woodbury, J. F. L., and Read, H. C. (1962). Canad. med. Ass. J., 86, 401.

Dacie, J. V., and Lewis, S. M. (1963). "Practical Haematology", 3rd ed., (a) p. 23; (b) pp. 32, 39, $51 ;(c)$ p. $84 ;(d)$ pp. 292-297. Churchill, London.
Empire Rheumatism Council Research Sub-Committee (1960). Ann. rheum. Dis., 19, 95.

Finch, C. A., Gibson, J. G., Peacock, W. C., and Fluharty, R. G. (1949). Blood, 4, 905.

Freireich, E. J., Ross, J. F., Bayles, T. B., Emerson, C. P., and Finch, S. C. (1957). J. clin. Invest., 36, 1043.

Hemmeler, G. (1946). Helv. med. Acta, 13, 20.

Huff, R. L., Tobias, C. A., and Lawrence, J. H. (1952). Acta haemat. (Basel), 7, 129.

Jacobsen, E., and Plum, C. M. (1943). Acta physiol. scand., $5,1$.

King, E. J., and Wootton, I. D. P. (1956). "Microanalysis in Medical Biochemistry", 3rd ed., p. 108. Churchill, London.

Krakoff, I. H., Karnofsky, D. A., and Burchenal, J. H. (1955). New Engl. J. Med., 253, 7.

Marcussen, P. V. (1938). Folia haemat. (Lpz.), 61, 49.

Marriott, H. J. L., and Peters, H. R. (1950). Ann. intern. Med., 32, 864.

Nilsson, F. (1948). Acta med. scand., Suppl. 210.

Price, A. E., and Leichtentritt, B. (1943). Ann. intern. Med., 19, 70.

Ropes, M. W., Bennett, G. A., Cobb, S., Jacox, R., and Jessar, R. A. (1959). Arthr. and Rheum., 2, 16.

Rubin, D., Weisberger, A. S., Botti, R. E., and Storaasli, J. P. (1958). J. clin. Invest., 37, 1286.

Scott, J. T., Porter, I. H., Lewis, S. H., and Dixon, A. St. J. (1961). Quart.J. Med., N.S. 30, 167.

Seip, M. (1953). Acta med. scand., Suppl. 282.

Sørensen, B. (1951). Ibid., 141, 27.

Trachtenberg, F. (1931). Folia haemat. (Lpz.), 46, 1.

Wintrobe, M. M., Huguley, C. H., McLennan, M. T., and Lima, L. P. de C. (1947). Ann. intern. Med., $27,529$.

_- Stowell, A., and Roll, R. M. (1939). Amer. J. med. Sci., 197, 698.

Wood, P. H. N., Harvey-Smith, E. A., and Dixon, A. St. J. (1962). Brit. med. J., 1, 669.

Valeurs réticulocytaires chez des malades atteints d'arthrite rhumatismale, avec des observations sur l'effet de la chrysothérapie sur la fonction de la moelle osseuse

\section{RÉSUMÉ}

(1) On étudia l'hématopoï̀se chez sept malades atteints d'arthrite rhumatismale soumis à la chrysothérapie. Une série de numérations globulaires, l'examen de la moelle osseuse aspirée et l'étude du fer radioactif administré n'apportèrent aucun fait qui puisse indiquer une dépression de la moelle. Un malade manifesta d'autres signes de toxicité de l'or et on nota aussi une légère réduction de l'absorption et conséquente utilisation sacrale du fer radioactif après la chrysothérapie, mais au cours des mois suivants la formule sanguine périphérique ne fut pas dérangée.

(2) On observa une augmentation irrégulière des réticulocytes chez des malades atteints d'arthrite rhumatismale évolutive. Cette augmentation disparaissait lorsque la maladie se trouvait améliorée par la chrysothérapie et ne se produisait pas chez des malades atteints d'arthrite rhumatismale non-évolutive. On conclut qu'une réticulocytose irrégulière est un trait inexpliquable de l'évolution de la maladie rhumatismale. 
Valores reticulocitarios en enfermos con artritis reumatoide, con observaciones respecto al efecto de la crisoterapia sobre la función de la médula ósea

\section{SUMARIO}

(1) Se estudió la hematopoyesis en siete enfermos con artritis reumatoide recibiento crisoterapia. Una serie de recuentos sanguíneos, el examen de la médula ósea aspirada y el estudio del hierro radioactivo administrado no revelaron evidencia alguna de depresión de la médula. Un enfermo manifestó otros signos de toxicidad del oro, notándose una cierta reducción de la absorpción y consecuente utilización sacral del hierro radioactivo después de la crisoterapia, pero en el curso de los meses siguientes la fórmula sanguínea periférica no fué perturbada.

(2) Se observó una elevación irregular de los reticulocitos en enfermos con artritis reumatoide activa. Esta elevación desaparecía al producirse la mejoría debida al oro y no tenía lugar en enfermos con artritis reumatoide inactiva. Se concluye que una reticulocitosis irregular es un rasgo de la actividad de la enfermedad reumatoide que no se puede explicar. 